\title{
MULTIPERSPEKTIF SOSIOLOGI DALAM AKUNTANSI: TELAAH AWAL
}

\author{
Rohmawati Kusumaningtias \\ Universitas Negeri Surabaya \\ rohmawatikusumaningtias@unesa.ac.id
}

Received: $23-03-2018$

Revised: 10-04-2018

ABSTRAK

Tujuan dari artikel ini adalah untuk menjelaskan mengenai multiperspektif sosiologi yang membentuk karakteristik masyarakat. Penjelasan tersebut dikaitkan dengan akuntansi sebagai salah satu unsur penting dalam membentuk realitas sosial. Artikel ini merupakan telaah konseptual dalam bentuk analisis deskriptif melalui literatur review. Uraian yang dipaparkan menjelaskan 4 perspektif, yaitu positivisme (fungsionalis), interpretif, kritis, dan posmodernis. Bagian akhir dari

Accepted: $19-04-2018$ artikel ini memberikan beberapa implementasi aplikasi perspektif sosiologi dalam ranah akuntansi sektor publik.

Kata kunci: akuntansi; multiperspektif; sosiologi.

\section{ABSTRACT}

The purpose of this article is to explain the sociological multiperspectives that configurate the characteristics of society. The explanation is related with accounting as one of the important elements in formalize social reality. This article is a conceptual study in descriptive analysis by literature review. The description presented 4 perspectives: positivism (functionalist), interpretive, critical, and postmodernist. The last section provides some implementations of sociological perspectives in the public sector accounting.

Keywords: accounting; multiperspective; sociology.

How to cite: Kusumaningtias, R. (2018). Multiperspektif Sosiologi Dalam Akuntansi: Telaah Awal. Akrual: Jurnal Akuntansi. 9 (2): 157-167.doi: http://dx.doi.org/10.26740/jaj.v9n2.p157-167

\section{PENDAHULUAN}

Perspektif merupakan cara pandang yang digunakan seseorang untuk memahami sesuatu. Dalam kehidupan sehari-hari, manusia memahami realitas tidaklah tunggal, karena setiap manusia mempunyai pemikirannya masing-masing. Sehingga tidak mungkin memaksakan satu model perspektif yang dapat berlaku bagi semua orang.
Demikian pula ranah penelitian. Refleksi diri dalam kehidupannya ikut menentukan kesadaran terhadap kebenaran realitas (Sudarma, 2010). Sifatnya tentu bersifat subjektif. Maka peneliti harus memahami pijakan metodologinya dalam penyampaian ilmunya.

Beberapa pakar mencoba untuk mempermudah pemahaman realitas dengan menggolongkannya ke dalam beberapa perspektif. 
Burrel \& Morgan (1979) membuat empat perspektif, yaitu paradigma fungsionalis, paradigma interpretif, paradigma radikal humanis, dan paradigma radikal strukturalis. Sementara Chua (1986) menyederhanakan menjadi tiga, yaitu paradigma fungsionalis, paradigma interpretif, dan paradigma kritis. Sementara Triyuwono (2012) menambahkan paradigma Chua dengan paradigma posmodernis. Artikel ini akan membahas empat klasifikasi yang merujuk pada ketiga pakar tersebut, sehingga akan membahas empat perspektif, yaitu (1) perspektif positivisme (fungsionalis), (2) perspektif interpretif, (3) perspektif kritis, dan (4) perspektif posmodernis.

Namun, penggolongan tersebut bukanlah merupakan kesempurnaan total dalam memahami realitas. Hal ini seperti yang dinyatakan oleh Poggi (1965) yang mengatakan bahwa " $a$ way of seeing, is also a way of not seeing". Artinya, empat perspektif memang digunakan untuk memahami realitas, tetapi bukan berarti sudah memenuhi cara pandang yang utuh. Perspektif lainnya bisa dimungkinkan untuk berkembang melalui proses tesis-antitesissintesis. Hal ini dapat saja terjadi, seperti berkembangnya cara pandang posmodernis yang dalam perjalanannya melengkapi perspektif lainnya, sehingga menjadi lebih utuh. Program Doktor Ilmu Akuntansi di Universitas Brawijaya, menambahkan wacana untuk mengembangkan perspektif religiusitas, spiritualis, dan kemanunggalan. Hal ini dikarenakan posmodernis belum mampu menjawab kebutuhan akan metodologi penelitian dengan ranah religius - spiritualis - kemanunggalan. Dengan demikian, perspektif akan terus berkembang melalui proses dialektika yang berlangsung secara berkesinambungan. Namun, untuk penulisan artikel ini, masih menggunakan empat perspektif seperti yang telah disebutkan sebelumnya.

\section{KLASIFIKASI PERSPEKTIF SOSIOLOGI DAN PENYEBAB PERBEDAANNYA}

Sebelum menjelaskan mengenai berbagai perspektif dalam sosiologi. Terlebih dahulu, harus memahami sosiologi dan masyarakatnya. Burrel \& Morgan (1979) membagi asumsi menjadi dua kutub yaitu dimensi subyektif dan obyektif. Pembagian tersebut dapat dilihat pada gambar 1. 
AKRUAL: Jurnal Akuntansi, volume 9, nomor 2, April 2018,

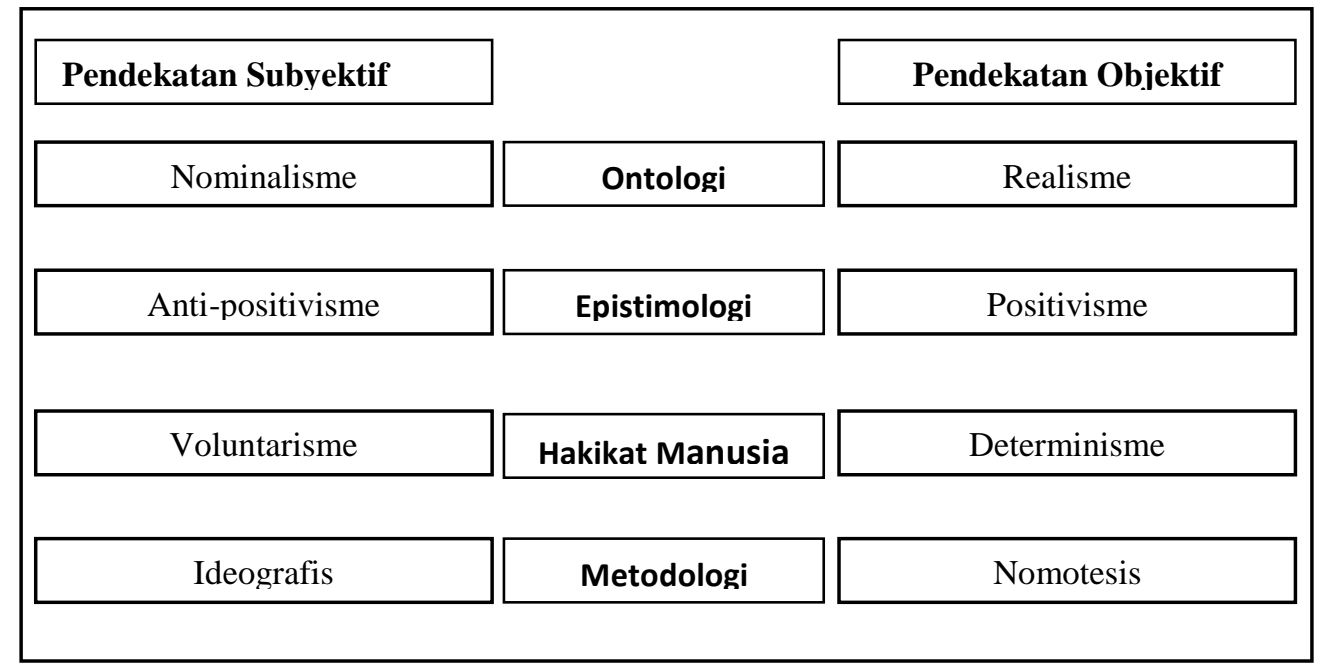

Gambar 1. Asumsi Mengenai Sosiologi

Sumber: (Burrel \& Morgan, 1979: 3)

Asumsi ontologis memberikan pemahaman mengenai fenomena yang diteliti, berasal dari luar kesadaran individu atau hasil bentukan kesadaran individu. Pada pandangan subyektif, dunia sosial diasumsikan sebagai suatu hal yang tidak lebih dari suatu label atau konsep yang membentuk realitas. Sehingga tidak ada struktur yang nyata dalam menjelaskan realitas. Sementara menurut pandangan obyektif, dunia sosial bebas dari pengaruh individu, karenanya tidak mampu melakukan perubahan.

Selanjutnya mengenai epistomologi yang terbagi menjadi positivisme dan anti-positivisme. Epistimologi memberikan penjelasan tentang bagaimana seseorang memahami ilmu pengetahuan, cara untuk menyerap dan mengomunikasikannya kepada lingkungan sosial (Chariri, 2009). Pada pandangan subyektif, dunia sosial dilihat sebagai sesuatu yang tidak pasti dan hanya dapat dipahami dari sudut pandang individu secara subyektif. Artinya, segala 159 sesuatu dipahami dari dalam diri manusia sendiri, bukan berasal dari luar. Sementara pandangan obyektif, berusaha menjelaskan dunia sosial kemudian memprediksi sesuatu yang akan terjadi. Positivis mencari keteraturan dan hubungan yang saling memengaruhi.

Berlanjut pada hakikat manusia (human nature) terhadap lingkungannya, yang dibedakan menjadi voluntarisme dan determinisme. Pada pandangan voluntarisme, individu dianggap sebagai manusia yang bebas (free will), mampu menentukan pilihan secara independen. Sebaliknya pada pandangan determinisme, individu dikendalikan oleh lingkungannya, sama sekali tidak mempunyai kebebasan dalam menentukan pilihan.

Terakhir, mengenai metodologi yang terbagi menjadi ideografis dan nomotesis. Pada pandangan ideografis, dunia sosial dilihat oleh individu secara langsung. Pemahaman atas realitas dapat diperoleh secara mandiri dari first Copyright @ 2018 AKRUAL: Jurnal Akuntansi 
Kusumaningtias, Multiperspektif Sosiologi...

hand. Dengan kata lain, membebaskan individu untuk bertindak sesuai dengan karakteristiknya pada saat melakukan pemahaman realitas. sementara dalam pandangan nomotesis, karakteristik individu tidak diperkenankan untuk terlibat, sebaliknya menyakini pada aturan dan teknik yang sistematis (cara yang digunakan dalam mengkonstruksi ilmu pengetahuan alam) dalam memahami realitas.

Dari pemahaman sosiologi di atas, didapatkan dua pandangan yang berbeda mengenai bentuk masyarakat. Pertama mengenai keteraturan atau integrasionis memberikan ciri masyarakat yang seragam dalam hubungan sosial, stabil, terintegrasi, terkoordinir, dan membentuk konsensus.
Kedua, mengenai konflik atau paksaan memberikan ciri masyarakat yang selalu berubah secara radikal, mempunyai konflik struktur yang mendalam, disintegrasi dan cenderung berkontrakdisi struktural.

$$
\text { Seperti yang telah dijelaskan di }
$$
pendahuluan, maka berdasarkan asumsi sosiologi dan bentuk masyarakat, artikel ini akan membahas empat perspektif yang langsung dikaitkan dengan akuntansi secara singkat sebagai ilustrasi untuk mempermudah pemahaman. Gambar 2 mencoba menyederhanakan pemahaman.

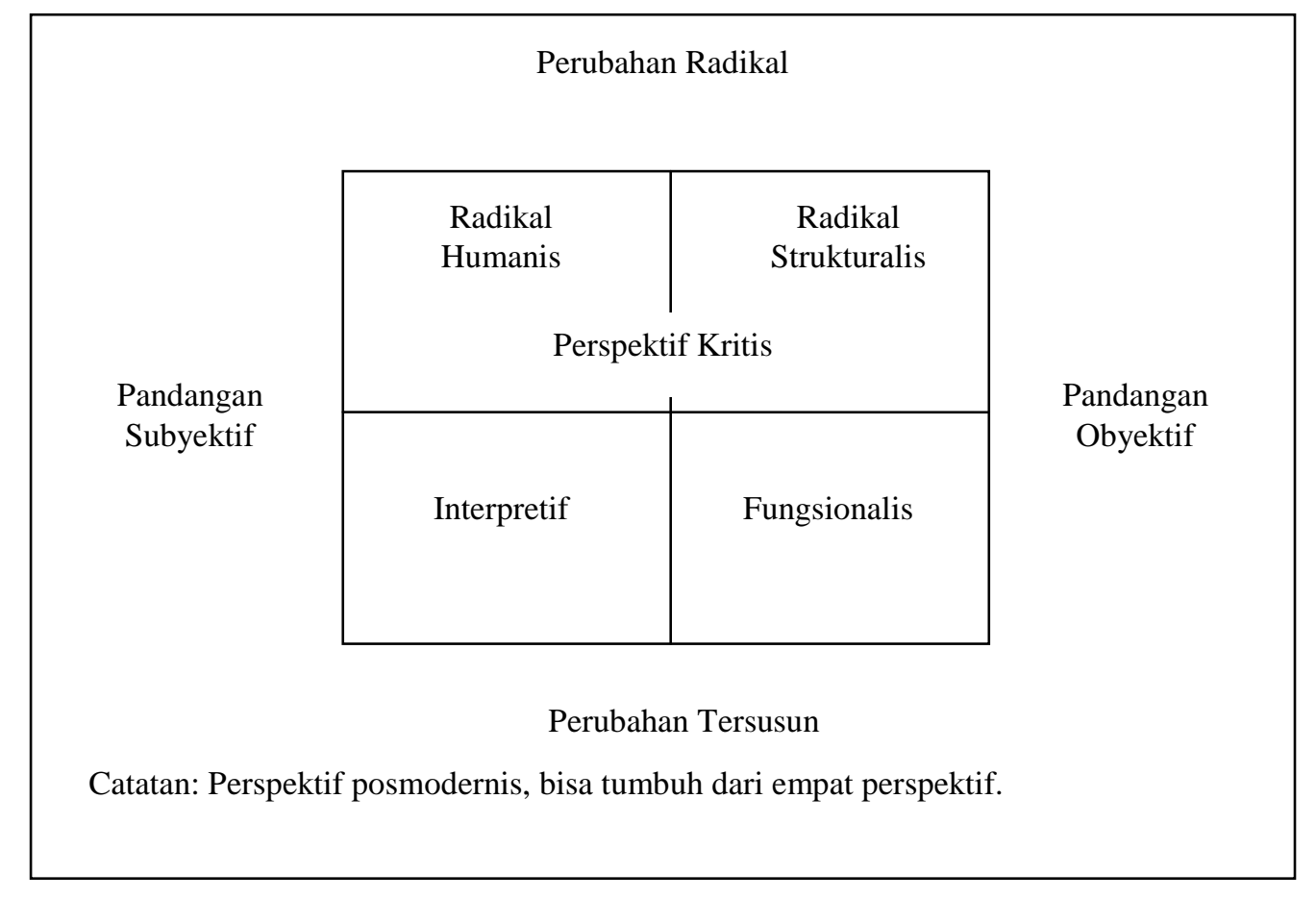

Gambar 2. Multiperspektif sosiologi

Sumber: (Burrel \& Morgan, 1979: 22) 
AKRUAL: Jurnal Akuntansi, volume 9, nomor 2, April 2018,

\section{Perspektif Fungsionalis (Positivisme)}

Perspektif ini berkeyakinan bahwa realitas obyektif secara mandiri menghadirkan manusia dan menjadikannya sesuatu yang dapat dikuasai (Chua, 1986; Efferin, 2015). Dalam sosiologi, individu beranggapan bahwa diri bersifat pasif. Perspektif ini melihat realitas sosial sebagai sesuatu yang tetap, bersifat obyektif, independen, dan berada di luar manusia.

Realitas yang diamati berada terpisah dari teori, sehingga diperlukan pengujian validitas ilmiah terhadap teori. Pencarian realitas sosial ditekankan pada pola hubungan yang saling memengaruhi dan dapat digeneralisasikan. Salah satu metode yang digunakan adalah survei dengan cara penarikan sampel kemudian diuji melalui statistik. Metodologinya adalah deterministik, yang menggap bahwa individu dipengaruhi oleh lingungkan yang telah ada dan bersifat tetap. Pandangan ini juga melihat bahwa dalam dunia sosial, perilaku manusia selalu bertujuan untuk maksimalisasi keuntungan.

Dalam konteks akuntansi, hal ini seperti yang digambarkan oleh Watts \& Zimmerman (1986: 2) bahwa "the objective of accounting theory is to explain and to predict accounting practice”. Akuntansi dianggap mapan dan layak jika mampu menjelaskan dan memprediksi realtias sosial. Dengan prinsip ini, perspektif fungsionalis berkeyakinan bahwa akuntansi bersifat universal, dapat digunakan oleh setiap individu, bahkan dengan struktur sosial, ideologi, dan budaya yang berbeda.
Kekuatan pada perspektif ini adalah ada pada prinsipnya yang universalitas dan sifatnya yang formal dan struktural. Prinsip tersebut menyebabkan akuntansi mampu berkembang lebih cepat karena dapat dipraktikan secara massal di setiap tempat. Namun demikian, prinsip tersebut juga mengandung kelemahan karena terlalu kaku ketika masuk dalam lingkungan sosial. Karena tidak membuka ruang bagi nilai-nilai sosial, budaya, dan ideologi lokal untuk mengambil peran. Sehingga mewadahi secara terbatas implementasi teori akuntansi.

\section{Perspektif Interpretivis}

Perpektif ini menekankan pada peranan bahasa, interpretasi dan pemahaman realitas sosial. Pendekatan ini cenderung memperhatikan sifat subyektivitas individu untuk terus menerus menciptakan realitas sosial dalam rangka berinteraksi dengan yang lain. Realitas dalam pandangan interpretif hanya merupakan label atau nama dari suatu konsensus kelompok. Menurut Chua (1986), fenomena keseharian membentuk pengalaman yang bersifat subyektif. Tujuan yang ingin dicapai adalah untuk memahami realitas sosial yang bersifat subyektif dan relatif. Dalam pandangan interpretif, individu memegang kendali atas pemberian makna dan penciptaan realitas.

Hasil temuan bersifat ideografik, tidak untuk dilakukan generalisasi dan memberikan keterbukaan atas sistem sosial, budaya, dan ideologi yang bersifat lokal. Ini pula yang menjadikan perspektif ini mempunyai kekuatan

Copyright@ 2018 AKRUAL: Jurnal Akuntansi 
dengan menyatunya para peneliti dan masyarakat sosial. Sehingga, perspektif ini masih sebatas pada upaya pemahaman makna.

Perspektif Kritis (Radikal Strukturalis Dan $\underline{\text { Radikal Humanis) }}$

Perspektif ini berkaitan dengan pengembangan pemahaman realitas sosial dalam bentuk kritik terhadap sesuatu yang telah mapan. Tujuan dari perspektif ini bukan hanya sekedar melakukan pemahaman, tetapi juga untuk membebaskan dan melakukan perubahan (Triyuwono, 2012; 241). Jika mengacu pada Burrel \& Morgan (1979) maka terdapat dua bentuk, yaitu radikal humanis dan radikal strukturalis.

Radikal strukturalis menekankan pada konflik mendasar sebagai hasil dari hubungan antara struktur dalam organisasi dengan realitas sosial, sedangkan radikal humanis menekankan pada kesadaran individu yang didominasi oleh ideologi. Perbedaan antara radikal strukturalis dan radikal humanis terletak pada dimensi subyektif-obyektif. Radikal strukturalis memperlakukan dunia sosial sebagai obyek eksternal dan memiliki hubungan yang terpisah dengan individu, sedangkan radikal humanis menekankan pada persepsi individu dan interpretasinya. Singkatnya, dalam radikal strukturalis, perubahan ditentukan melalui peraturan yang dibentuk, sementara dalam radikal humanis meyakini bahwa perubahan berasal dari kesadaran individu.

Dalam akuntansi, pembebasan dan perubahan dapat dilakukan dengan melakukan kritik terhadap praktik akuntansi modern yang telah mapan. Karena dalam pandangan kritis, masyarakat bersifat dinamis sehingga perubahan merupakan suatu hal yang pasti.

Kelemahan perspektif ini adalah karena masih berada dalam ranah materialisme. Sehingga individu memahami realitas berdasar pada wujud yang terlihat.

\section{Perspektif Posmodernis}

Kelemahan dari tiga perspektif sebelumnya, yaitu fungsionalis, interpretivis, dan kritis yang berada dalam ranah modernisme dijawab melalui perspektif posmodernis. Modernisme yang bersifat materi atau fisik, belum bisa melihat realitas secara utuh, karena mengabaikan mental dan spiritual (Triyuwono, 2012; 242). Melalui paradigma ini teori akuntansi dapat digunakan untuk membangkitkan kesadaran individu lebih dalam terhadap realitas yang lebih tinggi. Selain itu, perspektif ini juga bersifat terbuka untuk mensinergikan berbagai bentuk pendekatan, karena bersifat relatif.

\section{Penyebab Perbedaan Perspektif}

Saat ini yang mendominasi pemikiran masyarakat sosial adalah perspektif fungsionalis atau positivisme, disebut juga sebagai mainstream. Karena dianggap mengkaji ilmu pengetahuan secara empiris. Padahal ketiga perspektif lainnya, jika telah dipelajari dan dipahami dapat juga bersifat empiris, tidak hanya pada tataran konsep tetapi juga praktik. Sebab, dengan asumsi yang subyektif dan ideografik, 
mengizinkan peneliti untuk menyatu dengan masyarakat sehingga nilai-nilai sosial, budaya, serta ideologi terangkat dan tersalurkan. Dengan demikian paradigma selain positivisme, memberikan ruang lebih luas dalam mengkaji realitas.

Hal ini terjadi karena individu terlalu mengabsolutkan keyakinan akan pengetahuan. Sikap absolut terhadap ilmu, bisa disebabkan karena ketidaktahuan diri, pandangan diri, kesombongan diri, dan cinta akan diri. Hanh (2013) menjelaskan bahwa hal ini, membuat manusia terperangkap. Ibarat memanjat anak tangga, untuk lebih tinggi harus melepaskan anak tangga yang sedang kita injak. Jika diri yakin bahwa anak tangga yang diinjak adalah yang tertinggi, maka diri tidak akan mendaki. Bersiap menyerah di saat menyadari terdapat kebenaran yang lebih tinggi merupakan kunci yang harus dimiliki.

\section{DAMPAKNYA DALAM MELIHAT AKUNTANSI SEBAGAI FENOMENA SOSIAL}

Akuntansi sebagai salah satu ilmu yang menyajikan informasi kuantitatif, khususnya berupa keuangan dari suatu organisasi dijadikan dasar dalam pengambilan keputusan-keputusan ekonomi merupakan suatu produk sosial. Karena akuntansi saat ini berkembang lebih komprehensif, tidak lagi berdasarkan kalkulasi keuangan, namun juga menyajikan keterkaitan dengan sosial, bahkan lingkungan. Akuntansi berusaha untuk dikembangkan untuk menyajikan 163 informasi yang lebih seimbang dan memenuhi unsur keadilan, tidak terbatas kepada pemegang saham, investor, kreditor dan manajer, tetapi juga tenaga kerja, masyarakat sosial, dan kelestarian lingkungan. Sebagai ilmu sosial, relevansi akuntansi dapat dilihat dari tingkat manfaat yang mampu diberikan kepada lingkungannya (masyarakat dan alam).

Fenomena di atas mengindikasikan bahwa akuntansi tidak dapat dipisahkan dari lingkungan tempat diterapkannya dan tidak bisa netral dari kepentingan. Akuntansi dipengaruhi dan dibentuk oleh lingkungan yang kemudian memengaruhi lingkungan. Dengan demikian akuntansi memiliki dua arah, yaitu dipegaruhi dan memengaruhi lingkungannya (Triyuwono, 2012; 19). Dengan kata lain, akuntansi merupakan suatu ilmu yang tidak bebas dari nilai (value laden), merefleksikan nilai, ideologi, dan budaya yang ada dalam masyarakat. Pada saat bervalue laden, maka akuntansi tidak bisa dipandang hanya dari satu perspektif saja, tetapi lebih dari itu.

Sebagai contoh, ketika akuntansi diterapkan dalam suatu lingkungan, maka secara tidak langsung memengaruhi dan membentuk perilaku manajemen, pemegang saham, karyawan, dan individu-individu yang terkait dengan organisasi lingkungan tersebut. Namun, faktor-faktor lainnya juga berperan seperti sistem ekonomi, sosial, politik, peraturan, budaya, dan nilai masyarakat juga memengaruhi bentuk akuntansi. Hal ini sesuai dengan yang dikemukakan oleh Alagiah, Ratnatunga, \& Gaffikin (1998: 2) Copyright @ 2018 AKRUAL: Jurnal Akuntansi 
bahwa "accounting is not only a social construction but at the same time constructs a particular kind of society, the consequences of which are in need of investigation".

Kesadaran berakuntansi ini selaras dengan perkembangan klasifikasi perspektif sosiologi di atas. Akuntansi tidak hanya dipandang sebagai sesuatu yang konstan. Miller dan Napier (1993) menyebutkan bahwa "accounting changes in both content and form over time; it is neither solid nor immutable." In its earliest manifestation, accounting gave clear, transparent signs of a physical and social reality in space and time" (Macintosh, Shearer, Thornton, \& Welker, 2000: 16).

\section{RELEVANSI AKUNTANSI DAN SOSIOLOGI}

Seperti yang telah dijelaskan sebelumnya, akuntansi berfungsi seperti pedang bermata dua, yaitu tidak hanya dibentuk oleh lingkungan tetapi juga mampu membentuk realitas baru. Hines (1988) menyebutkan bahwa realitas diciptakan, dibentuk, dan dibatasi manusia berdasarkan persepsi dan kepentingan masingmasing. Begitu pun akuntansi, dapat membentuk realitas sendiri yang mampu memengaruhi aspek sosial kemasyarakatan. Sebagai contoh, laporan keuangan selama ini berfokus pada peningkatan laba.

Pandangan ini tidak lepas dari pengaruh lingkungan yang kapitalistik, laba merupakan representasi dari pemegang saham. Sehingga operasional perusahaan digunakan untuk tujuan maksimalisasi laba (Cho, 1999). Dengan memasukkan nilai-nilai kapitalistik, maka masyarakat sosial yang terbentuk nantinya akhirnya akan berbentuk kapitalis. Masyarakat kapitalis membentuk kekhawatiran tersendiri, seperti yang diungkapkan oleh (Norman Belding Macintosh, 2002: 125):

"While this may be all to the good for the individual accountant, there is a dark side. This concerns the consequences of such actions for society at large. In most nations today, the accounting profession has been granted a near monopoly on accounting and auditing services, legitimated on the basis that accountants will act in an objective, unbiased, and professional manner so that society at large can 'count on' the financial information produced for public consumption. But if these data are tainted by earnings management, then the public trust is violated, and if budget fiddles can badly mislead upper management who have the overall corporate interests in mind, what redeems accountants in private does not necessarily bring justice to the public."

Begitu pula yang dikatakan oleh (Alagiah et al., 1998: 29) bahwa:

“... that the human sciences were instruments of social control and were instrumental for a marginalised, categorised and excluded society. This is further validated with the above analysis where accounting and to a great extent economics, have been disciplines that construct a discourse about the object of income which is then used to subject human beings."

Hal ini juga menunjukkan bahwa realitas sosial bukanlah sesuatu yang given, obyektif 
AKRUAL: Jurnal Akuntansi, volume 9, nomor 2, April 2018,

dan pasif berada di luar diri manusia. Sebaliknya, manusia mampu memengaruhi lingkungannya. Perspektif akuntansi selain positivistik (disebut sebagai nonmainstream) mengakui bahwa akuntansi mampu melakukan dekonstruksi, sehingga nilai-nilai kapitalisme dapat dirubah menuju tatanan dunia baru. Maka akuntansi secara khusus paling tidak mampu melakukan perubahan pada akuntan sehingga nanti mampu memengaruhi masyarakat sosial.

\section{SOSIOLOGI DALAM AKUNTANSI SEKTOR PUBLIK}

Untuk melengkapi pemahaman mengenai keterkaitan sosiologi dan akuntansi, artikel ini akan mencoba untuk mengangkat beberapa penelitian yang telah dilakukan di bidang akuntansi sektor publik.

\section{Perspektif Interpretif}

Pada perspektif ini, penelitian dari Djamhuri (2009), mencoba diangkat sebagai contoh aplikasi. Penelitian ini dilakukan pada daerah yang dinamai sebagai Ratan Ombo Regencey (ROR) yang melakukan reformasi akuntansi. Metode New Instituitionalism Sosiolgy digunakan untuk memahami Performance Based Budgeting (PBB) dan akuntansi double entry untuk pemerintahan daerah. Penerapan PBB tidak sama dengan implementasi dari negara asalnya yaitu, United Kingdom. Karena adanya desentralisasi dan penentuan LAKIP. Karena perbedaan tersebut maka pastinya menimbulkan gejolak dan konflik dalam penerapan PBB yang 165 mempunyai budaya, karakteristik, dan ideologi berbeda antara negara asalnya dan Indonesia dalam menerapkan New Public Management (NPM).

Hasilnya menyatakan bahwa penerapan NPM seperti 'big bang' bagi pelaku sektor publik, akibatnya banyak peraturan yang tumpang tindih. Namun, karena adanya bantuan teknologi, peneliti beranggapan bahwa ini hanya merupakan masalah waktu karena membutuhkan sosialisasi lebih intensif. Dari penelitian ini, peneliti menyarikan bahwa akuntansi bukan hanya sekedar alat teknis, tetapi juga sebagai instrumen sosial yang sarat nilai yang terkandung didalamnya aspek ekonomi, sosial, dan budaya dari pihak-pihak terkait.

\section{$\underline{\text { Perspektif Kritis }}$}

Pada perspektif ini peneltian Pujiningsih (2013) digunakan sebagai contoh aplikasi perspektif kritis. Perubahan Badan Hukum Pendidikan menjadi Badan Layanan Umum merupakan salah satu model dari penerapan New Public Management (NPM). NPM dianggap sebagai praktik terbaik yang mampu mengefisiensikan alokasi sumber daya yang terbatas pada sektor publik. Permasalahannya adalah apakah benar dengan diterapkannya BLU sebagai aplikasi NPM mampu menjadikan universitas menjadi lebih efisien. Penelitian ini menggunakan pemikiran Habermas tentang kolonisasi sebagai alat analisis.

Dari hasil penelitian, didapatkan bahwa memang implementasi BLU belum diikuti Copyright@ 2018 AKRUAL: Jurnal Akuntansi 
dengan kesiapan sumber daya manusia yang dimiliki oleh universitas. Hal ini menyebabkan berbagai benturan dalam melakukan interpretasi peraturan. Kritik yang dilakukan disertai dengan solusi melalui anggaran partisipatif yang merefleksikan diri berkeTuhanan. Diharapkan dengan implementasi anggaran partisipatif ini, akuntansi dapat menjadikan individu-individu di universitas meningkat dalam hal kesadaran berkeTuhanan.

\section{KESIMPULAN}

Manusia mempunyai berbagai perspektif dalam melihat realitas sosial. Sosiologi sebagai ilmu pengetahuan yang mempelajari masyarakat beserta perilakunya perlu dikaji lebih mendalam. Artikel ini dimulai dengan penjelasan dua pendekatan subyektif-obyektif dalam sosiologi yang merujuk pada Burrel dan Morgan. Dari dua pendekatan tersebut terbentuklah karakteristik masyarakat, yaitu yang teratur dan berkonflik. Kemudian melakukan sintesis yang memunculkan empat persepektif sosiologi, yaitu perspektif fungsionalis (positivistik), perspektif interpretif, perspektif kritis (radikal strukturalis dan radikal humanis), serta perspektif posmodernis. Keempat perspektif tersebut dijelaskan secara singkat beserta keunggulan dan kelemahannya serta dikaitkan dengan akuntansi. Artikel ini juga menjelaskan penyebab perbedaan perspektif tersebut dikarenakan absolutisme mutlak individu terhadap satu perspektif saja.

Dari keempat persepektif sosiologis tersebut, pembahasan berikutnya dikaitkan dengan dampaknya dalam melihat akuntansi sebagai fenomena sosial. Akuntansi dipengaruhi dan dibentuk lingkungan yag kemudian memengaruhi dan membentuk lingkungan. Sehingga, akuntansi diharapkan mampu melakukan pembebasan dan perubahan bukan hanya secara materi, tetapi juga mental dan spiritual. Secara khusus perubahan minimal pada diri akuntan yang nantinya akan memengaruhi lingkungan sosial. Seperti yang dinyatakan oleh McKernan (2007: 175) bahwa:

"Just as academics have a
responsibility, to themselves, to
future generations of academics,
and to society, to protect and sustain
academic freedom, accountants
have a responsibility to protect and
develop the traditions, institutions,
and practices that sustain the
independence and integrity of their
judgment and of accounting rules."

Pembahasan terakhir dilengkapi dengan aplikasi sosiologi dalam ranah akuntansi sektor publik dengan mengambil penelitian dari perspektif interpretif dan perspektif kritik. Penelitan tersebut diantaranya adalah Djamhuri (2009) dan Pujiningsih (2013). Keduanya melakukan penelitian yang berkaitan dengan implementasi NPM.

\section{DAFTAR PUSTAKA}

Alagiah, R., Ratnatunga, J., \& Gaffikin, M. (1998). Foucault, Accounting Income and The Economist Status Of Indigenous Australian Families. In APIRA (pp. 1-30). Osaka. 
AKRUAL: Jurnal Akuntansi, volume 9, nomor 2, April 2018,

Burrel, G., \& Morgan, G. (1979). Sociological Paradigms and Organisational Analysis. Burlington: Ashgate.

Chariri, A. (2009). Landasan filsafat dan metode penelitian kualitatif. Workshop Metodologi Penelitian Kuantitatif Dan Kualitatif, Laboratorium Pengembangan Akuntansi (LPA), Fakultas Ekonomi Universitas Diponegoro Semarang, 31 Juli - 1 Agustus 2009.

Cho, D. (1999). The Impact Of A Price Cut On Net Income And Profit Margin. Journal of Financial and Strategic, 12(2), 83-94.

Chua, W. F. (1986). Radical Development of Accounting Thought. The Accounting Review, LXI(4), 601-632.

Djamhuri, A. (2009). A Case Study Of Governmental Accounting And Budgeting Reform At Local Authority In Indonesia: An Institutionalist Perspective. Universiti Sains Malaysia.

Efferin, S. (2015). Akuntansi, Spritualitas dan Kearifan Lokal Beberapa Agenda Penelitian Kritis. Jurnal Akuntansi Multiparadigma, 6(3), 466-480. https://doi.org/10.18202/jamal.2015.12. 6037 DOI:https://doi.org/10.18202/ jamal.201512.6037

Hanh, N, Thich. (2013). Memahami Pikiran Kita. Jakarta: Karaniya.

Hines, R. D. (1988). Fiancial Accounting: In Communicating Reality, We Construct Reality. Accounting, Management and Information Technologies, 13(3), 251261.
Macintosh, N. B. (2002). Accounting , Accountants and Accountability: Poststructuralist Positions. London: Routledge.

Macintosh, N. B., Shearer, T., Thornton, D. B., \& Welker, M. (2000). Accounting as simulacrum and hyperreality: perspectives on income and capital. Accounting, Organizations and Society, 25(1), 13-50. DOI: https://doi.org/10. 1016/S0361-3682(99)00010-0

McKernan, J. F. (2007). Objectivity in accounting. Accounting, Organizations and Society, 32(1-2), 155-180. DOI: https://doi.org/10.1016/j.aos.2006.03.00 8

Miller, P., \& Napier, C. (1993). Genealogies of calculation. Accounting, Organizations and Society, 18(7-8), 631-647. DOI: https://doi.org/10.1016/ 03613682(93)90047-A

Poggi, G. (1965). A Main Theme of Contemporary Sociological Analysis: Its Achievements and Limitations. British Journal of Sociology, 16. DOI: $10.2307 / 589157$

Pujiningsih, S. (2013). Pembebasan Kolonisasi Pendidikan Tinggi Badan Layanan Umum Melalui Akuntansi/Anggaran Emansipatoris. Universitas Brawijaya.

Sudarma, M. (2010). Paradigma Penelitian Akuntansi dan Keuangan. Jurnal Akuntansi Multiparadigma, 1(1), 97108.

Triyuwono, I. (2012). Akuntansi Syariah: Perspektif, Metodologi, dan Teori. Jakarta: Raja Grafindo. 